\title{
School Leadership for Sustainable Development: A Scoping Review
}

\author{
Idowu Mary Mogaji ${ }^{1} \&$ Paul Newton ${ }^{2}$ \\ ${ }^{1}$ College of Education, Department of Educational Administration, University of Saskatchewan, Saskatoon, \\ Canada \\ ${ }^{2}$ College of Education, Department of Educational Administration, University of Saskatchewan, Saskatoon, \\ Canada \\ Correspondence: Idowu Mary Mogaji, College of Education, University of Saskatchewan, Saskatoon, SK., S7N \\ 0X1, Canada. E-mail: imm761@usask.ca
}

Received: June 30, 2020

doi:10.5539/jsd.v13n5p15
Accepted: August 5, 2020

Online Published: September 28, 2020

URL: https://doi.org/10.5539/jsd.v13n5p15

\begin{abstract}
Sustainable development within educational institutions encompasses an array of objectives as outlined in Agenda 21 (United Nations [UN], 1992). We recognize in this paper that there are cognate terminologies in the field of sustainable development: Education for Sustainable Development (ESD), Education for Sustainability (EfS), Development Education (DE), and Sustainability Education (SE). As stated in the Education for Sustainable Development toolkit (McKeown, 2002), ESD is the terminology most often employed within UN documents; hence, we also employ ESD because it is the term utilized by UNESCO and at the international level. Thus, we avoid the many debates about these terminologies in this paper.

The fundamental interest of this review is to assess the current status of school leadership for sustainable development in the K-12 context. With the help of a scoping review, three literature databases were combed to achieve this purpose. The findings reveal school leaders' perceptions of sustainable development as well as their motives for engaging in ESD. Our analysis indicates that school leaders vaguely understand the term 'sustainable development,' and they interpret ESD from the lens of the environment and society. Thus, the economy component of ESD may be de-emphasized in implementation efforts.
\end{abstract}

Keywords: education for sustainable development, leadership, school leaders, scoping review, sustainable development

\section{Introduction}

Education is a formidable tool for influencing culture, conveying cultural principles to future generation of students, and shaping social change (Abraham, 2012). At the same time, educational institutions are contending with enormous social complexity and are embedded in historical, cultural, and economic systems that make it difficult to respond to current challenges. Educational institutions, however, can take on the challenges and proactively address them through schools (Boutte, 2008).

The United Nations (UN) declared a Decade of Education for Sustainable Development (ESD) between 2005 and 2014 and subsequently, a Global Action Program (UNESCO, 2014). This Global Action Program states that "there is a growing international recognition of Education for Sustainable Development as an integral element of quality education" (UNESCO, 2014, p. 9). ESD is a concept that embraces a new perception of education that strives to inspire students to accept control for creating and enjoying a sustainable future (UNESCO, 2002). UNESCO (2005) asserts that education molds the values that lead to viable actions that enable humans and other living organisms to exist and thrive in the world.

If ESD is to challenge the school community as a whole to promote sustainable development goals, school leaders' roles cannot be overlooked. School leaders establish the mood and vision of the school (Leithwood \& Jantzi, 2005), and they impact school ethos (Teasley, 2017). Additionally, the importance of school leaders in the implementation of school reform initiatives is often highlighted in educational policy documents (Authors, 2016); consequently, school leaders are seen as the primary agents in enacting educational change. Much of the achievement of transforming education to tackle sustainable development issues will be contingent on the ability of the school leader to communicate effectively with the school community and gain the commitment of staff and students (McKeown, 2013). Consequently, this scoping review recognizes a school as the core place of education. It equally 
acknowledges school leaders as critical stakeholders for facilitating the global sustainable development agenda. With this paper, we intend to demonstrate the nature and breadth of available research on school leadership for ESD in the K-12 school setting.

\section{Defining ESD}

ESD is a rising discipline which is becoming increasingly important within academic literature. ESD attempts to equip individuals with the knowledge and dexterity required to operate in an interdependent society. It is committed to making the planet more inhabitable for the present and succeeding generations (McKeown, 2013). Across the literature, the term ESD is used interchangeably with a variety of related terms. Sterling (2008) used the phrase Sustainable Education, Sauvé (1996) suggested Environmental Education, Huckle (1996) preferred Education for Sustainability (EfS), McKeown (2002) identified the need to differentiate Education about Sustainable Development and Education for Sustainable Development. We recognize the ambiguity surrounding the term; however, we will use ESD in this paper since it is the language widely used globally and across UN documents.

ESD will be described in terms of its three interdependent pillars: Society, Economy, and Environment. These three elements are not separate entities; they are intertwined. By way of illustration, a flourishing community banks on a thriving environment to supply food, potable water, unpolluted air, and resources for residents (McKeown, 2013). Understanding the interdependent pillars is an integral part of developing, implementing, and sustaining ESD (Siraj-Blatchford, 2009).

\subsection{Society}

The importance of the social context for sustainable development is articulated in the pillar of society. It involves fostering an awareness of people, customs, multiplicity, and social circles; their ways of living, thinking, working, and acting in line with context and history (Pressoir, 2008). It further acts as an essential lens for recognizing the benefit of educating students about peace, reconciliation, equity, and constitutional rights. (Simonstein-Fuentes, 2008). Producing a thoughtful body of students is the kernel for attaining the possibility of all humans cohabiting amicably, as one family.

\subsection{Economy}

The second pillar of ESD explores the many ways in which economic concerns interact with sustainability and sustainable development. It refers to humans and their affiliation with money, assets, resources, preservation, and financial equity (Siraj-Blatchford, 2009). How people comprehend and relate to economic matters is one facet of this pillar, as well as, recognizing economic expansion or downturn and its effect on humanity and the natural environment (Pressoir, 2008).

Furthermore, promoting equitable policy is an essential aspect of this pillar. Securing access to standard educational activities for students conceivably impact on developing a more sustainable society. Unbiased policies include educating for equal opportunities, advancing equal rights to education for male and female children, and providing equal employment opportunities for men and women. (Abraham, 2012; Center for Environment and Sustainability, 2008; Siraj-Blatchford, 2009). The economy pillar expects schools to enhance financial literacy as one of the components of a broader ESD program (Siraj-Blatchford, 2009).

\subsection{Environment}

Across the literature about ESD, the environment is a fundamental and central concept. The environmental pillar educates students about nature, the use of resources, and the vulnerability of the ecosystem (Pressoir, 2008). This pillar fosters harmony between the environment and people. The assumption is that if students are presented with clear images about this cordial and symbiotic affiliation between humans and nature, they would be motivated to appreciate and safeguard their environment (Chan, Grace, \& Lee, 2009; Fengfeng \& Yan, 2008).

The implementation of ESD in schools is an avenue to revamp education to become more significant or applicable to students and responsive to societal needs (Sterling, 2004). The principal objective of ESD is, therefore, to achieve building a sustainable community now and hereafter. Consequently, ESD is not about treating students as agents of redemption who will proffer solutions to all ESD problems, but as people who should be equipped with the knowledge, principles, skills, motivation, and mindsets needed to create a sustainable planet (Mckeown, 2013; Siraj-Blatchford, 2009).

\section{Why Leadership for ESD?}

Leadership as defined by Northouse (2004) is "a process whereby an individual influences a group of individuals to achieve a common goal" (p. 3). Fullan (2002) stated that leaders in successful corporations are individuals who 
engage others with their energy and are, in turn, rejuvenated by the actions, projects, and achievements of the group. Fullan (2016) further recognized the complexity of being a leader for change towards sustainable development. He stated that it requires several attributes such as persistence, knowledge of the components or building blocks of change, a solid recognition of the objective, emotional intelligence, receptivity to new visions and concepts, a commitment to working peacefully with others, and the capacity to create coherence.

Leadership has much to do with what is going to happen in the future of a school (Love, 1994). School leaders influence schools in several ways. They oversee the workforce, develop the culture, traditions, and language of the school, enact rules, and supervise teaching (Marzano, Waters, \& McNulty, 2005). Marzano et al. (2005) assert that school leadership is associated with several facets of school success, including but not limited to the effectiveness of educators, school ethos and values, and learning interventions for students. There is substantial backing indicating that principals have significant effect on schools (Barth, 2001; Fuller, Young, \& Orr, 2007).

Education for Sustainable Development involves managing change. School leaders are responsible for managing changes associated with reorienting education to address sustainable development goals - changes that must occur in the curriculum, procedures, plans, goals, and policies of a school system (McKeown, 2013). According to Hopkins and Jackson (2003), a "leader is a critical change agent, the guardian and facilitator of transitions" (p. 101). The Organization for Economic Cooperation and Development (OECD) (2008) also stated that school leaders could transform schools to accommodate external and societal changes. They reconcile internal school practices and externally introduced reforms. Therefore, the success of revamping education to tackle sustainable development goals rests on the shoulders of school leaders (McKeown, 2013). Hence, the advancement, communication, and implementation of ESD's vision should be among the school leader's most important tasks. We would suggest that school leaders consider ESD as an area of enormous importance, which requires an adequate understanding of the concept of ESD as well as practices supportive of educational change.

\section{Methodology}

We undertook a thorough scoping study to assess the research literature on school leadership for sustainable development in the K-12 school setting. The framework utilized for the review was the systematic methodological framework of Arksey and O'Malley (2005). Arksey and O'Malley (2005) stated that there are four reasons why a scoping review is conducted. One of the reasons, which is our motivation for embarking on this study, is: "to examine the extent, range, and nature of research activity" (p. 21). Scoping reviews are broad explorations which charts current literature in each discipline in terms of its nature, measures, quantity, and characteristics (Arksey \& O'Malley, 2005). They are of particular use when a body of literature has not been reviewed comprehensively. This is true in this case since research on ESD in K-12 schools tends to focus primarily on teacher and student outcomes. Not many studies have explored the enactment of ESD at K-12 school level with a focus on school leaders.

The remainder of this paper will conform with Arksey and O'Malley's (2005) framework. The framework consists of five stages namely: 1) problem formulation/research question, 2) literature search, 3) study selection, 4) data analysis, and 5) organizing and reporting the results.

\subsection{Research Question}

Problem formulation is the starting point of a scoping review. This stage guides the way search strategies are built (Arksey \& O'Malley, 2005). The research question that guided our review was: "What is the present state of the evidence on school leadership for sustainable development in K-12 school settings?" We are not ignorant of the fact that sustainable development is an ambiguous term that encompasses other words such as sustainability, environmental education, etc. We, therefore, embraced different terminologies to avoid missing relevant articles (Arksey \& O’Malley, 2005).

\subsection{Search Strategy}

In line with Arksey and O'Malley's (2005) framework (hereafter A\&O framework), recognizing relevant materials for a scoping study is the phase two of the frame. In identifying related research, a thorough and exhaustive search approach was employed to scope studies that examined school leadership for ESD in a K-12 context. Through consultation with an academic librarian, this study searched for academic literature in the following databases: ERIC (Ovid), ProQuest, and Education Database. We employed a combination of harvesting search terms and Boolean operators for the search (e.g. "school leadership" OR "educational leadership" OR "principal leadership" AND "sustainable development" OR sustainab* AND "K-12" OR "elementary school" OR "high school").

Consultation with the academic librarian was essential because of her expert skill in electronic databases and scoping review methodology. We selected these databases because they encompass an array of academic literature 
in the fields of humanities, arts, environmental sciences, and social sciences, amongst others. Articles published between 2005 and 2019 were selected. We theorized that the date 2005 would be an appropriate starting date for looking at the association between school leadership and sustainable development since the UN Decade of ESD was officially launched in 2005 . To further broaden the search and to ensure that the review was as thorough as possible, we conducted a further search of the grey literature. We combed Google Scholar and the references of the retrieved articles. Figure 1 represents a flow chart of the search procedure.
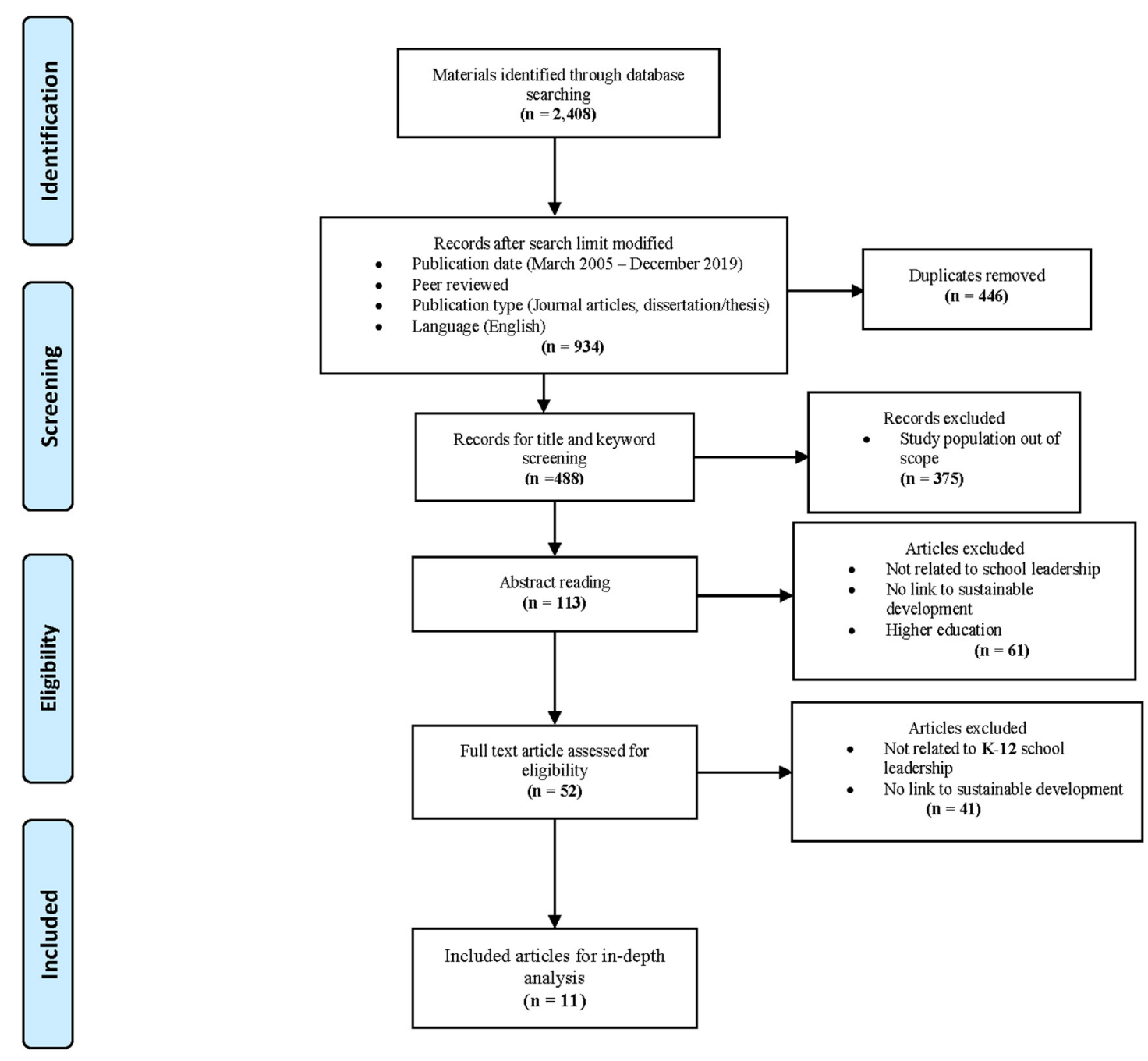

Figure 1. PRISMA flowchart of the selection process

\subsection{Study Selection}

The execution of the A\&O's framework stage three aligned with our PICo design. PICo stands for: Population, Interest, and Context. It is a useful tool for asking a focused question, and it is equally used to develop an effective search strategy (Miller, 2001). For this study:

- $\quad \mathrm{P}=$ Population $=$ School leaders/Principals

- $\quad$ I $=$ Interest $=$ Studies published between March 2005 and December 2019, studies on leadership for sustainable development 
- $\mathrm{Co}=$ Context $=\mathrm{K}-12$ school setting.

We define research studies in this paper as any type of systematic inquiry, which includes mixed methods research, quantitative research, systematic review, qualitative research, and meta-synthesis. These studies qualified for inclusion provided they examined ESD and other related terminologies such as EfS from a school leadership perspective. We excluded opinion pieces and editorials. After the elimination of duplicates, we utilized a selection process that examined the applicability of the studies identified in the search. At the initial phase of screening, we reviewed titles and keywords to eliminate articles that did not meet the inclusion criteria. We excluded titles that had terms such as higher education, colleges, and policies. In the second stage, we reviewed abstracts and excluded studies that had no relationship with school leadership and no link to sustainable development.

\subsection{Charting the Data}

Given the objective to investigate the breadth of available research on educational leadership for sustainable development in a K-12 context, this study included only articles that addressed topics of K-12 school leadership and sustainable development. After the review of materials through their titles and abstracts, full-text articles were assessed, and we found eleven papers to be eligible for review and data analysis.

We developed a data retrieval frame to ensure that the process of data extraction was standardized. For each included study, we recorded the following information:

- Author(s)

- Publication Year

- Country

- Research purpose/aim

- Research approach

- Research participants

- Research findings

We collated the data into an Excel worksheet, which was then exported into Microsoft Word document as the databased table (see Appendix 1). This stage ensured that data was obtained consistently across all the literature reviewed.

\subsection{Collating, Summarizing, and Reporting the Results}

Following A\&O's (2005) and Levac et al. (2010) approaches, we summarized results in two ways. The first way was through tables and figures, while the second approach utilized narrative summary to organize and summarize the results.

\section{Results}

The first search for literature generated 113 hits. From the initial array of articles, fifty-two full-text studies were retrieved and screened in accordance with the inclusion and exclusion measures set out previously. Of the fiftytwo research papers, forty-one studies did not meet the inclusion criteria. Thus, we retained eleven studies for the scoping review. We present the significant findings of the eleven-research papers in this section.

\subsection{Study Characteristics: Distribution by Country}

The articles scoped for review were carried out in six countries: Australia, Cyprus, England, Namibia, Sweden, and Wales. Table 1 highlights the quantity of studies in each country. 
Table 1. Distribution of included studies by country

\begin{tabular}{ll}
\hline Country & Frequency \\
\hline Sweden & $4(36.4 \%)$ \\
Australia & $2(18.2 \%)$ \\
England & $2(18.2 \%)$ \\
Cyprus & $1(9.1 \%)$ \\
Namibia & $1(9.1 \%)$ \\
Wales & $1(9.1 \%)$ \\
\hline
\end{tabular}

\subsection{Study Characteristics: Distribution by Year}

The included studies span from March 2005 to December 2019. The period with the fewest publications was between 2005 and $2009(n=2)$, while the period with the most papers was between 2015 and $2019(n=5)$. This implies that there is little advancement in the number of research conducted on school leadership for sustainable development in the $\mathrm{K}-12$ context.

\subsection{Study Characteristics: Distribution by Types of Study}

The bulk of articles reviewed were qualitative studies. Several qualitative methods were utilized, including phenomenological, portrait, and social network approaches (see Table 3). Two of the articles did not explicitly state the data analysis technique(s) used.

Table 3. Analytical methods

\begin{tabular}{ll}
\hline Analytic approaches & Frequency of occurrence \\
\hline Empirical analysis & $1(9.1 \%)$ \\
Phenomenological analysis & $2(18.2 \%)$ \\
Social network analysis & $1(9.1 \%)$ \\
Portrait analysis & $1(9.1 \%)$ \\
Statistical analysis & $2(18.2 \%)$ \\
Narrative summary & $2(18.2 \%)$ \\
\hline
\end{tabular}

\subsection{Interpreting Sustainable Development}

There are disparities in the scoped literature regarding the definitions of ESD (Jickling, 2010). One frequently reiterated criticism of ESD is that its interpretation is too broad and that the concept of sustainable development is controversial. In the scoped study, which explored how two headteachers implemented ESD in their respective schools, one of the principals stated that sustainable development "is a catchall term" (Bottery, Wright, \& James, 2012, p.18). The principal had this to say about ESD:

First, it can be primarily about the curriculum and recycling and making sure the school is as green as it can be. And to really work, this cannot be an isolated enthusiasm: it is a lot more than just learning to turn the lights off or doing eight weeks of recycling. If it is going to be about ensuring the sustainability of the planet, and green issues, then it has to be embedded all the way through, an integral part of the school. (pp. 18-19)

Zachariou and Kadji-Beltran's (2009) study investigated Cypriot elementary school heads' knowledge of ESD. Findings showed that most of the definitions given by ten of the twelve principals were connected to the environmental pillar of sustainable development and restricted to the preservation of the natural environment. The socio-economic facets of sustainable development were infrequently stated. One principal said that "sustainable development is the development of the society and at the same time, it entails respect for and conservation of the environment and the planet as a whole" (Zachariou \& Kadji-Beltran, 2009, p. 323). Another principal stated that sustainable development is all about green schools: "full of plants, and areas where children can be creative and happy ... promote various environmental activities aiming at the protection of the environment, the preservation of our natural heritage" (Zachariou \& Kadji-Beltran, 2009, p. 327). 
Consequently, the lack of a comprehensive understanding of the concept of ESD could make it difficult for leaders to engage fully in ESD activities. This could, in turn, lead to difficulties in creating awareness and convincing the school staff to buy into the vision of ESD.

\subsection{Motives of the Principals}

Principals in the included studies indicated several reasons for engaging in ESD. Some principals cited their dedication to matters that affect humanity and the future as essential motivation. They cited the social aspect of ESD (democracy, basic rights, freedom etc.) as the primary motive. This could imply that some school heads utilize ESD to execute ethical, democratic, and multicultural education.

Additionally, findings revealed that the readiness of principals to enact ESD goals is contingent on their perceptions of ESD. That is, whether ESD is perceived as an additional school priority or a channel to provide increased quality in education (Birney \& Reed, 2009). As highlighted by Evans (2015), some motivations for why schools and their leaders participate in ESD include political pressure from decision makers outside the school and for reasons of personal interest. According to Evans (2015), the identified reasons for engaging in ESD relate mostly to extrinsic motives. He concluded that school leaders are more interested in the approval they get from others and the feeling of self-worth rather than a genuine interest in the goals and values of ESD.

\subsection{A Collegial Approach}

School leaders of the included studies encouraged a collaborative approach to ESD implementation. In Bush Rangers school (Pepper \& Wildy, 2008), leadership was diffused amongst team members, with apparent high trust and distributed recognition for achievements (Scott, 2013; Spillane, 2005). The ESD coordinator of Bush Rangers school (Pepper \& Wildy, 2008) sought assistance from teachers to work with students. He shared responsibility with other teachers and strived to boost interest for ESD among his learners in activities and across the curriculum. Similarly, in Mogren and Gericke's (2019) study, principals recognized the significance of including others in their ESD ambitions and implementation strategies. The collegial approach was also employed to firmly secure ESD in partnership within and between schools. The external collegial approach enabled school leaders to initiate collaborations with other schools, create opportunities to learn from others, and determine common grounds regarding the implementation of ESD (Mogren \& Gericke, 2019).

\subsection{A Holistic Idea}

Principals recognized the importance of anchoring a comprehensive concept of ESD. They stressed the need to pin this holistic notion across all aspects of the school. They contended that within practices of change, it is vital to have the targets of ESD properly secured in school policies and all the regional steering documents. By so doing, school leaders said that it would give room for uniformity and consistency within and across schools (Mogren \& Gericke, 2019). Thus, by incorporating ESD goals in official policies and documents, principals could legitimize and justify their implementation of ESD (Mogren \& Gericke, 2019). Additionally, some principals asserted that political decisions made outside the school are crucial to legitimizing ESD.

The holistic concept identified in the scoped studies is essential at all stages and in all sections of the school (Gough 2005). It would ensure that the school environment, school culture, curriculum, programs, practices, and policies are intertwined and employed in building a more viable future. The holistic approach ensures that sustainable development is lived as well as taught (McKeown \& Hopkins, 2007).

\section{Discussion}

Our analysis illustrates that school leaders' understanding of ESD is inadequately developed with an inability to recognize the three dimensions: environment, economy, and society. The consensus about the three components and their interactive relation on the broader literature (McKeown \& Hopkins, 2003; Sauvé, 2002) was not detected in the scoped studies as school leaders defined ESD either from the environmental pillar or society pillar. The difficulty of a clear description of ESD lies in the complexity of the term. Sustainable development, as revealed in the scoped studies, is a highly contested term. Bonnett (2002) contends that the term is extremely challenging and receptive to a range of interpretations.

Likewise, Stables and Scott (2002) refer to sustainable development as a paradoxical compound policy slogan. Jickling calls it an oxymoron (Jickling, 1994). Despite the lack of agreement on a specific definition of sustainable development and ESD, we argue that they should not be disqualified as concepts. There might be no distinct or universal definition of ESD; however, there is at least a global understanding of the concept of sustainable development that education addresses (Pigozzi, 2003). UNESCO (1997) captures this agreement: 
a sustainable future. They may not be able to provide a precise definition of sustainable development...[however] they smell the problem in the air; they taste it in their water; they see it in more congested living spaces and blemished landscapes; they read about it in the newspaper and hear about it on the radio. (p. 6)

Based on the above statement, school leaders should thrive to understand the issues ESD set out to address. That is, school leaders ought to have an intuitive and informed sense of the goals of ESD, and the urgent need to create a sustainable future as a requirement for leading for sustainable development in educational institutions. Such understanding and clarity will enable school leaders to take informed action (UNESCO, 1997). In line with this, Scott (2005) stated that transforming the ethos of a school in alignment with ESD principles will require school leaders who have an unclouded perception of the concept of sustainable development and understand that "ESD involves more than a line of unconnected activities" (p. 4).

Harris (2008) attempted to link leadership to sustainable development. She stated that schools would achieve ESD goals when all stakeholders are involved. The implication of this is that school leaders' roles as brokers and promoters of ESD in the broader community are paramount to the success of school based ESD initiatives. Similarly, Breiting, Mayer, and Mogensen (2005) claimed that an essential aspect of ESD implementation is the ability of a school head to collaborate with different stakeholders. Engagement at all levels and shared leadership are features of ESD implementation, also highlighted by Leo and Wickenberg (2013). They assert that leadership that creates a school culture which influences teachers and students and supports their ideas and projects is essential for ESD implementation. These studies suggest that the implementation of ESD is not a task for one person. An essential element of leadership for ESD is a shared agenda that unites all stakeholders around a common goal. School leadership for ESD will have long-term success when the school leader involves and engages everyone within the system. Diversity in the views and perspectives of others can be tremendously rewarding. It could create not only broader support but a more robust approach that reflects the full array of stakeholder's knowledge and ideas.

\section{Limitations}

This scoping review is not devoid of some limitations. Firstly, only articles printed in English from 2005 to 2019 were included; hence, relevant literatures in other languages could have been missed. Our choice to review only studies printed in English was necessitated by time constraints and limited resources to employ translation services for articles available in other languages. Also, we did not assess the quality of the articles. This is often regarded as a weakness of the scoping review. However, Arksey and O'Malley (2005) assert that this is not a limitation because scoping studies have various reasons for which they are undertaken. Our goal was to reveal the scope of research on school leadership for ESD in the K-12 school setting. A final limitation is the relatively few studies conducted on school leaders' impact on school-based ESD - although this paucity of research is also an interesting finding given the importance placed on school leaders in the school reform literature.

\section{The Implication for Practice and Research}

From the search of the literature, we found that leadership for sustainable development in higher institutions (universities and colleges) has been researched extensively. We also uncovered that within the K-12 education system, there is existing literature that examines the implementation of ESD in classrooms and the effects ESD has on student outcomes. However, there are minimal published studies that have examined the relative impact of $\mathrm{K}-12$ school leadership on ESD. These findings indicate how underdeveloped leadership research is from the core business of sustainable development in the K-12 education system. School leaders are "leaders with strategic competencies. They can translate strategy into action, align people and organizations, and determine effective intervention points" (Davies \& Davies, 2004, p. 30). It is, therefore, vital that school leaders' in-service training courses encompass describing the concept of sustainable development. The training process should equip school leaders with the expertise needed to aid the implementation of ESD in their respective educational institutions.

\section{Conclusion}

This paper presented a review of research on leadership for ESD from a K-12 context. It utilized the process of scoping review to analyze articles included in electronic databases to gain information on the number of articles and related research topics published. A significant finding is that of school leaders' conceptualization of sustainable development. Most school leaders understood ESD as environmental education, which often does not move beyond the activities related to recycling. As such, consideration for school leader training and development in ESD is warranted. Researchers in these studies found evidence of collaborative and distributed leadership for the successful implementation of ESD in schools. Based on this, further study of the types of leadership that best supports the implementation of ESD would be valuable. Based on the findings discussed in this paper, we contend 
that if ESD is to be ascribed the required priority, and if a school leader's task to enact ESD is to be encouraged, then ESD goals must be expressed in the vision and policies of schools. By so doing, school leaders will have resources for legitimizing and justifying the implementation of ESD to ensure holism in the implementation of ESD initiatives across curriculum, pedagogical approaches, community engagement, and school activities.

Author Contributions: IMM and PN conceived of this paper and designed the study. IMM conducted a preliminary review of the literature with the assistance of a skilled librarian. IMM retrieved the data from the included studies. All authors prepared the manuscript, read, reviewed, and approved the final manuscript.

Funding: The authors did not receive funding for this study.

Acknowledgment: The authors would like to acknowledge the University of Saskatchewan, College of Education Librarian Maha Kumaran for her assistance in helping with the search and retrieval of all the relevant studies used in this review.

Conflicts of Interest: The authors declare no conflict of interest.

\section{References}

Abraham, N. (2012). Towards sustainable national development through well managed early childhood education. World Journal of Education, 6(3), 43-48. https://doi.org/10.5430/wje.v2n3p43

Arksey, H., \& O'Malley, L. (2005). Scoping studies: Towards a methodological framework. International Journal of Social Research Methodology, 8(1), 19-32. https://doi.org/10.1080/1364557032000119616

Barth, R. S. (2001). Teacher leader. Phi Delta Kappan, 82(6), 443-449. https://doi.org/10.1177/003172170108200607

Bennell, S. (2015). Education for sustainable development and global citizenship: Leadership, collaboration, and networking in primary schools. International Journal of Development Education and Global Learning, 7(1), $5-32$.

Birney, A., \& Reed, J. (2009). Sustainabilility and renewal: Findings from the leading sustainable schools research project. Nottingham: National College for Leadership of Schools and Children's Services.

Bonnett, M. (1999). Education for sustainable development: A coherent philosophy for environmental education. Cambridge. Journal of Education, 29(3), 313-324. https://doi.org/10.1080/0305764990290302

Bonnett, M. (2002). Education for sustainability as a frame of mind. Environmental Education Research, 8(1), 313-24. https://doi.org/10.1080/13504620120109619

Bottery, M. (2011). Refocusing educational leadership in an age of overshoot: Embracing an education for sustainable development. International studies in educational administration, 39(2), 3-16.

Bottery, M., Wright, N., \& James, S. (2012). Personality, moral purpose and the leadership of an education for sustainable development. Education 3-13, 40(3), 227-241. https://doi.org/10.1080/03004279.2010.512563

Boutte, G. (2008). Beyond the illusion of diversity: How early childhood teachers can promote social justice. The Social Studies, 99(4), 165-173. https://doi.org/10.3200/TSSS.99.4.165-173

Breiting, S., Mayer, M., \& Mogensen, F. (2005). Quality criteria for ESD schools: Guidelines to enhance the quality of education for sustainable development. Europe: SEED and ENSI Networks.

Center for Environment and Sustainability. (2008). The Gothenburg recommendations on education for sustainable development. Chalmers: University of Gothenburg.

Chan, B., Choy, G., \& Lee, A. (2009). Harmony as the basis for education for sustainable development: A case example of Yew Chung international schools. International Journal of Early Childhood, 41, 35-48. https://doi.org/10.1007/BF03168877

Davies, B., \& Davies, B. (2004). Strategic leadership. Strategic Leadership and Management, 24(1), 29-38.

Evans, L. (2015). University professors as academic leaders: Professorial leadership development needs and provision. Educational Management Administration and Leadership, 45(1), 123-140. https://doi.org/10.1177/1741143215578449

Fengfeng, L., \& Yan, L. (2008). Building a harmonious society and ECE for sustainable development. In I. Pramling -Samuellson, \& Y. Kaga (Eds.), The contribution of early childhood education to a sustainable society (pp. 43-52). Paris: UNESCO.

Fullan, M. (2002). Leadership for sustainability. Principal Leadership, 3(4), 1-9. 
Fuller, E., Young, M. D., \& Orr, M. T. (2007). Careers in motion: An examination of the career paths of principals in Texas. Paper presented at the annual meeting of the American Educational Research Association. Chicago, IL.

Gough, A. (2005). Sustainable schools: Renovating educational processes. Applied Environmental Education and Communication, 4(4), 339-351. https://doi.org/10.1080/15330150500302205

Harris, A. (2008). Distributed leadership: According to the evidence. Journal of Educational Administration, 46(2), 172-188. https://doi.org/10.1108/09578230810863253

Hopkins, D., \& Jackson, D. (2003). Building the capacity for leading and learning. In A. Harris, C. Day, M. Hadfield, D. Hopkins, A. Hargreaves, \& C. Chapman (Eds.), Effective leadership for school improvement (pp. 84-105). London: Routledge Falmer.

Huckle, J. (1996). Realising sustainability in changing Times. In J. Huckle, \& S. Sterling (Eds.), Education for sustainability (pp. 3-17). London: Earthscan Publications.

Jickling, B. (1994). Studying sustainable development: Problems and possibilities. Canadian Journal of Education, 19(3), 231-240.

Jickling, B. (2010). Reflecting on the $5^{\text {th }}$ world environmental education congress, Montreal, 2009. Journal of Education for Sustainable Development, 4(1), 25-36. https://doi.org/10.1177/097340820900400110

Kanyimba, A., Katewa, E., \& Claassen, P. (2015). The contribution of education for sustainable development to transformational leadership among selected Namibian school principals. Open Journal of Social Sciences, 3, 186-196. https://doi.org/10.4236/jss.2015.33028

Leithwood, K., \& Jantzi, D. (2005). A review of transformational school leadership research. Paper presented at the annual meeting of the American Educational Research Association. Montreal, Canada.

Leo, U., \& Wickenberg, P. (2013). Professional norms in school leadership: Change efforts in implementation of education for sustainable development. Journal of Educational Change, 14(4), 403-422. https://doi.org/10.1007/s10833-013-9207-8

Levac, D., Colquhoun, H., \& O'Brien, K. K. (2010). Scoping studies: Advancing the methodology. Implementation Science, 5(69), 1-9. https://doi.org/10.1186/1748-5908-5-69

Lovejoy, T. E. (1994). People and biodiversity. Nature Conservancy, 29-33.

Marzano, R., Waters, T., \& McNulty, B. (2005). School leadership that works. Alexandria, Virginia: ASCD.

McKeown, R. (2002). Education for sustainable development toolkit, version 2. Knoxville: University of Tennessee. Retrieved from http://www.esdtoolkit.org

McKeown, R. (2013). Teaching for a brighter more sustainable future. Kappa Delta Pi Record, 49(1), 1220. https://doi.org/10.1080/00228958.2013.759824

McKeown, R., \& Hopkins, C. (2003). EE $\neq$ ESD: Defusing the worry. Environmental Educational Research, 9(1), 117-128. https://doi.org/10.1080/13504620303469

McKeown, R., \& Hopkins, C. (2007). International network of teacher education institutions: Past, present and future. Journal of Education for Teaching, 33(2), 149-155. http://dx.doi.org/10.1080/02607470701259408

Miller, G. (2001). The development of indicators for sustainable tourism: Results of a Delphi survey of tourism researchers. Tourism Management, 22(4), 351-362. https://doi.org/10.1016/S0261-5177(00)00067-4

Mogren, A., \& Gericke, N. (2017a). ESD implementation at the school organisation level, part 1: Investigating the quality criteria guiding school leaders' work at recognized ESD schools. Environmental Education Research, 23(7), 972-992. https://doi.org/10.1080/13504622.2016.1226265

Mogren, A., \& Gericke, N. (2017b). ESD implementation at the school organisation level, part 2: Investigating the transformative perspective in school leaders' quality strategies at ESD schools. Environmental Education Research, 23(7), 993-1014. https://doi.org10.1080/13504622.2016.1226266

Mogren, A., \& Gericke, N. (2019). School leaders' experiences of implementing education for sustainable development: Anchoring the transformative perspective. Sustainability, 11, 1-21. https://doi.org/10.3390/su11123343

Northouse, P. (2004). Leadership: Theory and practice (3rd ed.). Thousand Oaks, CA: Sage.

Pepper, C. (2014). Leading for sustainability in western Australian regional schools. Educational Management 
Administration and Leadership, 42(4), 506-519. https://doi.org/10.1177/1741143213502193

Pepper, C., \& Wildy, H. (2008). Leading for sustainability: Is surface understanding enough? Journal of Educational Administration, 46(5), 613-629.

Pigozzi, M. J. (2003). Reorienting education in support of sustainable development through a focus on quality education for all. Paper presented at GEA Conference. Tokyo: UNESCO.

Practice: A Development Education Review, 6, Spring, 63-68.

Pressoir, E. (2008). Preconditions for young children's learning and practice for sustainable development. In I. Pramling-Samuellson, \& Y. Kaga (Eds.), The contribution of early childhood education to a sustainable society (pp. 57-62). Paris: UNESCO.

Rauch, F. (2002). The potential of education for sustainable development for reform in schools. Journal of Environmental Education Research, 8(1), 43-51. https://doi.org/10.1080/13504620120109646

Sauvé, L. (1996). Environmental education and sustainable development: A further appraisal. Canadian Journal of Environmental Education, 1, 7-34.

Sauvé, L. (2002). Environmental education: Possibilities and constraints. Connect: UNESCO International Science Technology and Environmental Education Newsletter, 27, 1-4.

Scott, W. (2005). ESD: What sort of decade? What sort of learning?

Scott, W. (2013). Developing the sustainable school: Thinking the issues through. The Curriculum Journal, 24(2), 181-205. https://doi.org/10.1080/09585176.2013.781375

Simonstein-Fuentes, S. (2008). Education for peace in a sustainable society. In I. Pramling-Samuellson, \& Y. Kaga (Eds.), The contribution of early childhood education to a sustainable society (pp. 37-42). Paris: UNESCO.

Siraj-Blatchford, J. (2009). Editorial: Education for sustainable development in early childhood. International Journal of Early Childhood, 41(2), 9-22.

Spillane, J. P. (2005). Distributed Leadership. The Educational Forum, 69, 143-150. https://doi.org/10.1080/00131720508984678

Stables, A., \& Scott, W. (2002). The quest for holism in education for sustainable development. Journal of Environmental Education Research, 8(1), 53-60. https://doi.org/10.1080/13504620120109655

Sterling, S. (2004). Higher education, sustainability and the role of systemic learning. In P. Corcoran, \& A. Wals (Eds.), Higher education and the challenge of sustainability: Contestation, critique, practice, and promise (pp. 47-70). Dordrecht: Kluwer.

Sterling, S. (2008). Sustainable education: Towards a deep learning response to unsustainability. Policy \&

Teasley, M. L. (2017). Organizational culture and schools: A call for leadership and collaboration. Children and Schools, 39(1), 3-6. https://doi.org/10.1093/cs/cdw048

UNESCO. (1997). Educating for a sustainable future: A transdisciplinary vision for concerted action. Paris: UNESCO.

UNESCO. (2002). Education for sustainability - From Rio to Johannesburg: Lessons learnt from a decade of commitment. Paris: UNESCO.

UNESCO. (2005). Decade for education for sustainable development 2005-2014: International implementation scheme. Paris: UNESCO.

UNESCO. (2014). Roadmap for implementing the global action programme on education for sustainable development. Paris: UNESCO.

United Nations. (1992). Agenda 21: United Nations Conference on Environmental \& Development, Rio de Janeiro. New York: United Nations Division for Sustainable Development.

World Commission on Environment and Development (WCED). (1987). Our common future. Oxford: Oxford University Press.

Zachariou, A., \& Kadji - Beltran, C. (2009). Cypriot primary school principals' understanding of education for sustainable development: Key terms and their opinions about factors affecting its implementation. Environmental Education Research, 15(3), 315-342. https://doi.org/10.1080/13504620902862902 


\section{Appendix 1. Evidence details of included studies}

\begin{tabular}{|c|c|c|c|c|c|c|c|}
\hline $\begin{array}{l}\text { Author } \\
\text { and } \\
\text { Year }\end{array}$ & Country & Study & Research Aim & Research Question & $\begin{array}{l}\text { Research } \\
\text { Design and } \\
\text { Methods }\end{array}$ & Sample & Findings \\
\hline $\begin{array}{l}\text { Bennell } \\
(2015)\end{array}$ & $\begin{array}{l}\text { North- } \\
\text { West } \\
\text { Wales }\end{array}$ & $\begin{array}{l}\text { Education for } \\
\text { Sustainable } \\
\text { Development } \\
\text { and Global } \\
\text { Citizenship: } \\
\text { Leadership, } \\
\text { Collaboration, } \\
\text { and } \\
\text { Networking in } \\
\text { Primary } \\
\text { Schools. }\end{array}$ & $\begin{array}{l}\text { To explore the role, } \\
\text { features, and } \\
\text { characteristics of } \\
\text { leadership, } \\
\text { partnership, and } \\
\text { networking in the } \\
\text { promotion of } \\
\text { Education for } \\
\text { Sustainable } \\
\text { Development }\end{array}$ & $\begin{array}{l}\text { - What roles do } \\
\text { leadership, } \\
\text { collaboration, and } \\
\text { networking play in the } \\
\text { development of } \\
\text { ESDGC in primary } \\
\text { schools? } \\
\text { - To what extent do } \\
\text { schools and their } \\
\text { teachers have links } \\
\text { and partnerships with } \\
\text { others outside of the } \\
\text { school? } \\
\text { - What kinds of } \\
\text { networking, support, } \\
\text { or partnerships are } \\
\text { perceived to be most } \\
\text { useful? } \\
\text { - Is there evidence that } \\
\text { distributed leadership, } \\
\text { collaboration, } \\
\text { support, } \\
\text { networking impact on } \\
\text { teachers' } \\
\text { understanding and } \\
\text { teaching competence? }\end{array}$ & $\begin{array}{l}\text { Qualitative } \\
\text { Interpretive } \\
\text { Approach } \\
-\quad \text { Initial } \\
\text { Survey } \\
\text { - Semi- } \\
\text { structured } \\
\text { Interviews } \\
\text { (Headteache } \\
\text { rs, teachers, } \\
\text { and support } \\
\text { staff) } \\
\text { - Social } \\
\text { Network } \\
\text { Analysis } \\
\text { - School } \\
\text { documents } \\
\text { - School } \\
\text { Website }\end{array}$ & $\begin{array}{ll}5 & \text { Primary } \\
\text { Schools } & \\
\text { ( } \mathrm{n}= & 33 \\
\text { Interviews; } & 34 \\
\text { Survey } & \\
\text { responses) } & \end{array}$ & $\begin{array}{l}\text { - Findings revealed that } 13 \text { out of } \\
17 \text { most frequently stated factors } \\
\text { clustered under leadership, } \\
\text { distributed leadership, collective } \\
\text { or teamwork, and networking } \\
\text { - Principals exhibited positive } \\
\text { attitudes towards ESDGC. } \\
\text { - Principals equally cited their } \\
\text { personal interests as motives for } \\
\text { their promotion of ESDGC } \\
\text { - Headteachers in these schools } \\
\text { had several measures they used to } \\
\text { promote the development of } \\
\text { ESDGC. One the measures taken } \\
\text { was the appointment of a } \\
\text { coordinator to oversee ESDGC. } \\
\text { - All of the schools had extensive } \\
\text { external networks }\end{array}$ \\
\hline $\begin{array}{l}\text { Bottery } \\
(2011)\end{array}$ & England & $\begin{array}{l}\text { Refocusing } \\
\text { Educational } \\
\text { Leadership in } \\
\text { an Age of } \\
\text { Overshoot: } \\
\text { Embracing an } \\
\text { Education for } \\
\text { Sustainable } \\
\text { Development }\end{array}$ & $\begin{array}{l}\text { To argue that a } \\
\text { detailed knowledge } \\
\text { of the } \\
\text { interrelationships } \\
\text { between } \\
\text { environmental, and } \\
\text { social, pillars of } \\
\text { economic } \\
\text { sustainable } \\
\text { development is an } \\
\text { area with which } \\
\text { educational leaders } \\
\text { need to be familiar. } \\
\text { - To reframe the } \\
\text { focus of educational } \\
\text { leadership for } \\
\text { sustainable } \\
\text { development. }\end{array}$ & $\begin{array}{l}\text { - What should } \\
\text { educational leaders be } \\
\text { concerned with? } \\
\text { - What ideals should } \\
\text { educational leaders be } \\
\text { influencing their } \\
\text { colleagues towards? } \\
\text { - How do local, } \\
\text { national, and global } \\
\text { contexts affect ESD? }\end{array}$ & $\begin{array}{l}\text { Conceptual } \\
\text { Paper }\end{array}$ & Not applicable & $\begin{array}{l}\text { - Limited understanding of the } \\
\text { concept of ESD. } \\
\text { - Limited examples of good } \\
\text { practice regarding leadership for } \\
\text { sustainability. } \\
\text { - Paucity of time to appreciate the } \\
\text { complexities of ESD. } \\
\text { - Leadership for ESD requires an } \\
\text { interdisciplinary frame } \\
\text { - Educational leaders need to be } \\
\text { competent and confident in such a } \\
\text { multidisciplinary reframing of } \\
\text { issues. }\end{array}$ \\
\hline $\begin{array}{l}\text { Bottery, } \\
\text { Wright, } \\
\text { and } \\
\text { James } \\
(2012)\end{array}$ & $\begin{array}{l}\text { United } \\
\text { Kingdom }\end{array}$ & $\begin{array}{l}\text { Personality, } \\
\text { Moral Purpose, } \\
\text { and the } \\
\text { Leadership of } \\
\text { an Education } \\
\text { for Sustainable } \\
\text { Development }\end{array}$ & $\begin{array}{l}\text { To explore how two } \\
\text { headteachers } \\
\text { implemented } \\
\text { education for } \\
\text { sustainable } \\
\text { development in } \\
\text { their respective } \\
\text { schools }\end{array}$ & $\begin{array}{l}\text { How is effective } \\
\text { leadership for ESD to } \\
\text { be developed? }\end{array}$ & $\begin{array}{l}\text { Portrait } \\
\text { methodolog } \\
\text { y } \\
\text { - Two } \\
\text { portraits } \\
\text { - Document } \\
\text { analysis } \\
\text { - } \\
\text { Observation }\end{array}$ & 2 Headteachers & $\begin{array}{l}\text { - The schools had inadequate } \\
\text { understanding of sustainable } \\
\text { development. } \\
\text { - Work in sustainable } \\
\text { development was uncoordinated } \\
\text { and was repeatedly restricted to } \\
\text { special occasions instead of being } \\
\text { an essential component of the } \\
\text { school curriculum. } \\
\text { - Results from one of the schools } \\
\text { showed that unless the school can } \\
\text { maintain its attainment at a certain } \\
\text { acceptable level, talks about ESD } \\
\text { will be slapped down, and the } \\
\text { principal will be reminded of }\end{array}$ \\
\hline
\end{tabular}


getting other important targets up.

- Limited official backing of ESD

from the government.

- School workforce (teachers and headteachers) lack grounding for the knowledge base of ESD.

- One of the principals recognized the importance of ESD; however, she was comfortable to allow others in the school lead ESD because of her other priorities.

- The principals felt their major challenge was micromanagement. Micro-management implies the inability of Government to allow school leaders to use their professional judgment appropriately. So, they cannot do much if the government does not give them a free hand.

\begin{tabular}{lll}
\hline $\begin{array}{l}\text { Kanyim } \\
\text { ba, Namibia }\end{array}$ & $\begin{array}{l}\text { The } \\
\text { Contribution }\end{array}$ & of ESD the impact \\
Katewa & of Education & transformational \\
Claasse & for Sustainable & leadership. \\
$\mathrm{n}$ & Development & \\
$(2015)$ & to & \\
& Transformatio \\
& nal Leadership \\
& among \\
& Selected \\
& Namibian \\
& School \\
& Principals
\end{tabular}

- What are school
principals' views on
integrating ESD as a
vehicle for
transformational
leadership?
- What are the
challenges that school
principals foresee as
regards the integration
of ESD as a tool for
transformational
leadership in
Namibian schools?

Namibian schools?

- What are school principals' suggestions regarding the inclusion of ESD as a vehicle for transformational leadership in

Namibian schools?
Phenomenol $\mathrm{n}=8$ principals - The findings of the research ogy -

Questionnair

e indicated that ESD could be used to develop transformational leadership in schools because it presents an opening for everyone to be engaged in environmental preservation through ESD.

- Distribution of responsibilities, availability of means of communication, and managing natural resources of the schools are ways to integrate ESD into transformational leadership.

- ESD is a problematic concept and principals find it difficult to persuade everyone (parents, teachers, students) to embrace it.

- Principals highlighted some actions to be taken in ensuring that ESD becomes a tool for transformational leadership. Such as creating awareness and instituting committees to tackle environmental matters in the school.

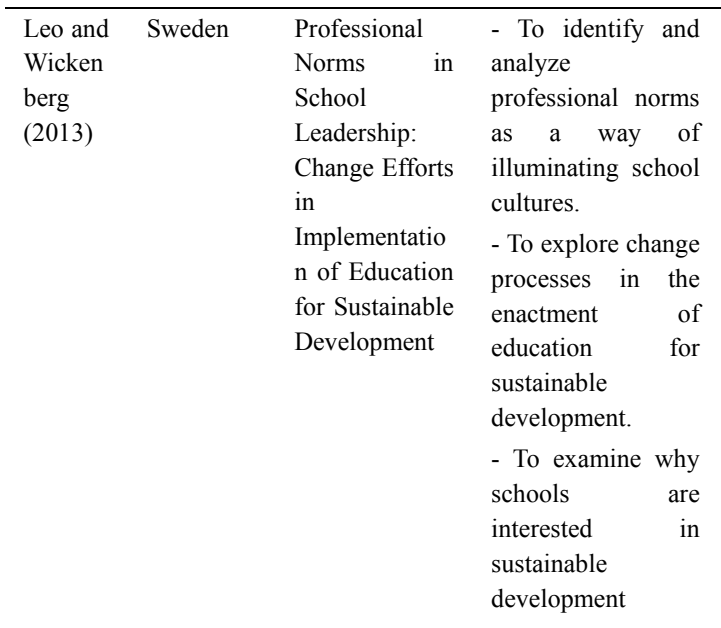

\begin{tabular}{|c|c|c|}
\hline \multirow{4}{*}{$\begin{array}{l}\text { - How do principals } \\
\text { communicate and } \\
\text { view their roles as } \\
\text { leaders in the } \\
\text { implementation of } \\
\text { education } \\
\text { sustainable } \\
\text { development? }\end{array}$} & \multirow{2}{*}{$\begin{array}{l}\text { Mixed } \\
\text { methods } \\
\text { - } \\
\text { Questionnair } \\
\text { es } \\
\text { - Interviews }\end{array}$} & $\begin{array}{l}3 \text { schools: } \\
\text { Principals (n = } \\
\text { 10) }\end{array}$ \\
\hline & & $\begin{array}{l}\text { School } \\
\text { teachers (n } \\
120)\end{array}$ \\
\hline & $\begin{array}{l}\text { - Focus } \\
\text { group } \\
\text { interview }\end{array}$ & $\begin{array}{l}\text { School } \\
\text { teachers (n } \\
71)\end{array}$ \\
\hline & & $\begin{array}{l}\text { School } \\
\text { teachers (n } \\
34)\end{array}$ \\
\hline
\end{tabular}

- Principals' responses suggested several motives for having an ESD profile. Majority of the principals cited their devotion and interest in matters that affect the future of their community and the planet as important motives.

- The principals were also motivated by the solid support they received from other principals and leadership teams

- Findings from the focus group interview revealed that principals did not have a uniformed concept of sustainable development.

- They described sustainable development as lacking a shared umbrella. 


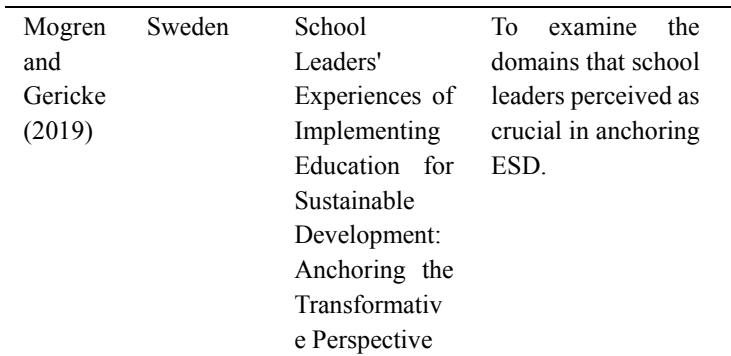

$\begin{array}{lll}\text { Which domains of the } & \text { Empirical } & 10 \quad \text { Upper } \\ \text { school organization } & \text { Analysis } & \text { Secondary } \\ \text { do school leaders find } & -\quad \text { Semi- } & \text { School } \\ \text { important in } & \text { structured } & (\mathrm{n}=14 \text { leaders }) \\ \text { anchoring ESD to } & \text { Interviews } & \\ \text { make it permanent and } & & \\ \text { long-lasting? } & \end{array}$

long-lasting?

School leaders highlighted the significance of ESD and the political directive to implement it.

- The transformative oriented schools in the study emphasized that anchoring structures and practices are essential to developing a holistic concept of ESD.

- ESD in group 1 school followed a leadership approach that included a strong distribution of responsibility among the school's workforce.

- Results showed the value of collegial effort in organizing ESD in teaching and learning.

- School leaders of the transformative schools voiced the need to legitimize ESD within their schools. They equally stated the importance of collaborating with stakeholders beyond the four walls of the school.

\begin{tabular}{|c|c|c|c|}
\hline $\begin{array}{l}\text { Mogren } \\
\text { and } \\
\text { Gericke } \\
(2017 a)\end{array}$ & Sweden & $\begin{array}{l}\text { ESD } \\
\text { Implementatio } \\
\mathrm{n} \text { at the School } \\
\text { Organisation } \\
\text { Level, Part 1: } \\
\text { Investigating } \\
\text { the Quality } \\
\text { Criteria } \\
\text { Guiding } \\
\text { School } \\
\text { Leaders' Work } \\
\text { at Recognized } \\
\text { ESD Schools }\end{array}$ & $\begin{array}{l}\text { To analyze the } \\
\text { implementation of } \\
\text { ESD at the school } \\
\text { level by asking } \\
\text { school leaders } \\
\text { about their generic } \\
\text { choices, } \\
\text { engagement, and } \\
\text { the way they shape } \\
\text { their educational } \\
\text { practice to achieve } \\
\text { high quality in } \\
\text { education }\end{array}$ \\
\hline
\end{tabular}

Mogren Sweden

and

Gericke

(2017b)

$\begin{array}{ll}\text { ESD } & \text { To investigate how } \\ \text { Implementatio } & \text { the school } \\ \mathrm{n} \text { at the School } & \text { organization-level } \\ \text { Organization } & \text { quality strategies } \\ \text { Level, Part 2: } & \begin{array}{l}\text { adopted by the } \\ \text { Investigating }\end{array} \\ \text { leaders of ESD } \\ \text { Transformativ } & \text { active schools relate } \\ \text { e Perspective } & \text { adoption of the } \\ \text { in School } & \text { transformative } \\ \text { leaders' } & \text { perspective for ESD } \\ \text { Quality } & \text { implementation. }\end{array}$

Strategies at

ESD Schools.

$\begin{array}{llll}\text { - What quality criteria } & \text { Case Study } & 10 & \text { upper } \\ \text { do school leaders at } & \text { Approach } & \text { secondary } \\ \text { active ESD schools } & -\quad \text { Semi- } & \text { schools } \\ \text { recognize? } & \text { structured } & -14 \quad \text { school } & \text { and } \\ \text { - What is the relative } & \text { Interviews } & \text { leaders } & \end{array}$
importance of these criteria, according to the school leaders?

- Can these quality criteria be used to identify general guiding principles (principal quality criteria) for quality work at the school organizational level?

- To what degree do
school leaders in the most ESD active schools in Sweden use quality criteria that support

transformative and transmissive

educational

perspectives in their quality work?

- What transformative quality strategies, if any, can be identified to guide school leaders in the most ESD-active schools in Sweden?

\begin{tabular}{|c|c|c|c|c|c|c|c|}
\hline $\begin{array}{l}\text { Pepper } \\
(2014)\end{array}$ & $\begin{array}{l}\text { Western } \\
\text { Australia }\end{array}$ & $\begin{array}{l}\text { Leading for } \\
\text { sustainability }\end{array}$ & $\begin{array}{l}\text { To explore how } \\
\text { school leaders }\end{array}$ & $\begin{array}{l}\text { - How do school } \\
\text { leaders in regional }\end{array}$ & $\begin{array}{l}\text { Case study } \\
\text { methodolog }\end{array}$ & $\begin{array}{l}8 \text { schools }(5 \\
\text { primary }\end{array}$ & $\begin{array}{l}\text { - Results showed that school } \\
\text { leaders displayed contrasting }\end{array}$ \\
\hline & & in Western & perceive their & schools perceive their & & schools; & levels of comprehending \\
\hline & & $\begin{array}{l}\text { Australian } \\
\text { Regional } \\
\text { Schools }\end{array}$ & $\begin{array}{l}\text { leadership of the } \\
\text { Australian } \\
\text { Sustainable Schools } \\
\text { (AuSSI-WA) }\end{array}$ & $\begin{array}{l}\text { leadership of the } \\
\text { AuSSI-WA initiative? }\end{array}$ & - Interviews & $\begin{array}{lr}\text { senior high } \\
\text { schools, and } 1 \\
\text { district high } \\
\text { school) }\end{array}$ & $\begin{array}{l}\text { sustainability. They all were } \\
\text { enthusiastic about embedding } \\
\text { sustainability values in their } \\
\text { schools. }\end{array}$ \\
\hline
\end{tabular}

- The findings of this scoping study suggest that the generic quality assumption of variation and shared leadership is emphasized more strongly among ESD active schools in Sweden.

- School leaders also stated that the school's vision must be distributed and shared for ESD to be effective.

\begin{tabular}{|c|c|c|}
\hline $\begin{array}{l}\text { Mixed } \\
\text { Methods } \\
\text { Approach } \\
\text { - Interviews } \\
\text { - Concept } \\
\text { maps were } \\
\text { analyzed } \\
\text { quantitativel } \\
\text { y }\end{array}$ & $\begin{array}{l}10 \text { upper } \\
\text { secondary } \\
\text { schools } \\
\text { consisting of } 14 \\
\text { school leaders } \\
\text { - Pilot study of } \\
40 \text { school } \\
\text { leaders } \\
\text { attending an in- } \\
\text { service training } \\
\text { course }\end{array}$ & $\begin{array}{l}\text { - The relative emphasis on } \\
\text { transformative qualities varied } \\
\text { between schools in the study, } \\
\text { indicating that school leaders } \\
\text { within these schools seem to } \\
\text { adopt many different quality } \\
\text { strategies and ways of } \\
\text { implementing ESD }\end{array}$ \\
\hline
\end{tabular}


- Several leaders have been area; 2 senior

classroom successful in accessing external teachers, and 1 classroom funding to raise their school profiles and provide tangible teacher) evidence of education for sustainability in their school.

- Each participant confirmed their perception of their role as leading the sustainability agenda within their schools

School leaders in this study outlined actions they have taken to embed education for sustainability in their respective schools.

\begin{tabular}{llllccc}
\hline Pepper & Western & Leading for & To investigate how Not stated & Phenomenol & Government \\
and & Australia & Sustainability: & education for & ogical & Secondary \\
Wildy & & Is Surface & sustainability is & Approach & Schools \\
$(2008)$ & & Understanding & conceptualized, & Semi- & structured \\
& & Enough? & incorporated across & curriculum and led & interviews
\end{tabular}

- Some of the research participants' understanding of sustainability was abstract,

- One of the research participant acknowledged the need for EfS. The onus to spearhead education for sustainability rested on this participant.

- Findings showed that it is critical to have a profound knowledge of sustainability before attempting to influence sustainable development.

- Much of the sustainable development education in this study is delivered in isolated pockets, with limited collaboration among participants and their collegial networks

- In this study, education for sustainability is provided whimsically, without resources and communicating the vision for the future.

\begin{tabular}{|c|c|c|c|c|c|c|c|}
\hline $\begin{array}{l}\text { Zachari } \\
\text { ou and } \\
\text { Kadji- } \\
\text { Beltran } \\
(2009)\end{array}$ & Cyprus & $\begin{array}{l}\text { Cypriot } \\
\text { Primary } \\
\text { School } \\
\text { Principals' } \\
\text { Understanding } \\
\text { of Education } \\
\text { for Sustainable } \\
\text { Development } \\
\text { Key Terms and } \\
\text { their Opinions } \\
\text { about Factors } \\
\text { Affecting Its } \\
\text { Implementatio } \\
\mathrm{n}\end{array}$ & $\begin{array}{l}\text { To explore primary } \\
\text { school principals' } \\
\text { perceptions of } \\
\text { sustainable } \\
\text { development }\end{array}$ & $\begin{array}{l}\text { - What are the } \\
\text { principals' perceptions } \\
\text { of the concept of } \\
\text { sustainable } \\
\text { development? } \\
\text { - What are their ideas } \\
\text { about sustainable } \\
\text { schools? } \\
\text { - What are their } \\
\text { opinions about factors } \\
\text { facilitating or } \\
\text { hindering the } \\
\text { operation of } \\
\text { sustainable schools? }\end{array}$ & $\begin{array}{l}\text { Mixed } \\
\text { methods } \\
\text { approach } \\
\text { - Open and } \\
\text { closed- } \\
\text { ended } \\
\text { questionnair } \\
\text { e } \\
\text { - Interviews }\end{array}$ & $\begin{array}{l}261 \text { schools } \\
\text { Survey (n = } \\
320), \quad 150 \\
\text { principals } \\
\text { answered and } \\
\text { returned the } \\
\text { questionnaire } \\
\text { Interviews ( }= \\
12 ; 7 \text { women } \\
\text { and } 5 \text { men) }\end{array}$ & $\begin{array}{l}\text { - Findings in this study reveal a } \\
\text { weakness in defining sustainable } \\
\text { development. Most of the } \\
\text { principals (10 of the } 12 \\
\text { principals) definitions were } \\
\text { theoretical and linked solely to the } \\
\text { environmental dimensions of SD. } \\
\text { - Findings further reveal that the } \\
\text { term sustainable school is a } \\
\text { concept vaguely understood by } \\
\text { the principals. Sustainable } \\
\text { schools' operation is limited to } \\
\text { environmental conservation. } \\
\text { - Principals identified barriers for } \\
\text { organizing schools according to } \\
\text { ESD principles such as lack of } \\
\text { policy, lack of time, shortage of } \\
\text { funds, deficient training courses, } \\
\text { and the overwhelming number of } \\
\text { programs implemented by }\end{array}$ \\
\hline
\end{tabular}


schools.

- Principals also identified the absence of a holistic, systematic, and long-term policy of ESD in the official Cyprus educational policy as a limiting factor in promoting ESD

- Findings reveal that the implementation of ESD across

Cyprus is optional for schools and teachers

\section{Copyrights}

Copyright for this article is retained by the author(s), with first publication rights granted to the journal.

This is an open-access article distributed under the terms and conditions of the Creative Commons Attribution license (http://creativecommons.org/licenses/by/4.0/). 